\title{
The Effect of Writing Proficiency onWriting Planning Strategy Use: A Case Study of Saudi Learners of English
}

\author{
Eid Alhaisoni \\ English Department, University of Ha'il, Saudi Arabia \\ E-mail: eid.alhaisoni@uoh.edu.sa
}

Received: May 16, 2012 Accepted: May 30, 2012 Published: September 1, 2012

doi:10.5296/ijl.v4i3.1808 URL: http://dx.doi.org/10.5296/ijl.v4i3.1808

\begin{abstract}
This study investigated English language writing planning strategies (WPSs) of Saudi Arabian third-year male university students and the effect of writing proficiency on the frequency of use of these strategies. The participants were 197 Saudi learners of English as a Foreign Language attending their third year of university in Saudi Arabia. The data used in this study were obtained using a questionnaire and semi-structured interviews. The collected data were computed and analysed via descriptive statistics, the $t$ test, and one-way repeated measure ANOVA. The participants reported applying most of the strategies in the questionnaire at a level higher than the midpoint of the scale. They reported applying only a few of those strategies (i.e. less than three) but all strategies were reported to be used by at least one of the subjects. Concerning English writing proficiency, a significant difference between good and poor writers was found in the frequency of overall use of WPSs $(z=-2.527, P=.011)$. The results showed that good writers claim to use WPSs more frequently than do poor writers.
\end{abstract}

Keywords: Writing planning strategies, Writing process, Planning strategies, Writing proficiency 


\section{Introduction}

Writing appears to be a difficult, complex cognitive task. Writers do not simply put their ideas on paper in a straightforward way. Smith (1989) claimed that writing is 'not simply a direct production of what the brain knows or can do at a particular moment' (p. 33). The act of writing forces writers to demonstrate control of a number of variables simultaneously. Such an effort forces a vast burden of responsibility on writers to capture their thoughts on paper. Simply stated, writing 'requires thought, discipline, and concentration' (White 1987, 266). As Widdowson (1983) writes, ' ...In writing one frequently arrives at a destination not originally envisaged, by a route not planned for in the original itinerary' (p. 41). Hence, the activity of writing may lead to an unknown destination as a result of moving in unplanned directions. In addition, it 'seems to require an expense of effort disproportionate to the actual results...Most of us seem to have difficulty in getting our thought down on paper' (Widdowson 1983, 34). Flower and Hayes (1981a) state that 'People start out writing without knowing exactly where they will end up; yet they agree that writing is a purposeful act' (p. 377).

In fact, writers struggle with their cognitive experiences. In other words, they think up and search out ideas, as well as organising, developing, revising, and shaping those ideas in the best manner to express their messages to readers in a logical, unambiguous, and clear way. Accordingly, Raimes (1985) argued that the task of writers is not easy because when 'writers struggle with what to put down next or how to put it down on paper, they often discover something new to write or a new way of expressing their ideas. They discover a real need for finding the right word and the right sentence'. Therefore, there is a strong relationship between thinking and writing. According to Flower and Hayes (1981a, 366), 'writing is a set of distinctive thinking processes' that writers goes through. The present study aimed mainly to explore writing planning strategies (WPSs) in a new context and so to contribute to the field of second-language (L2) writing. It considered the effect of writing proficiency on WPSs, which will provide the L2 literature with crucial information on such writing strategies. Finally, this study aimed to describe and analyse the WPSs that undergraduate Saudi Arabian male students of English as a Foreign Language (EFL) use while writing in their L2 (i.e. English).

This study is of particular significance within the Saudi males EFL context. To the best of my knowledge there has been only one empirical study examined the writing-composition processes used by Saudi males when writing and their use of writing strategies when writing in English. Generally, most of the literature to date regarding the writing skills of Arabic-speaking students learning English as a foreign language has concerned the product of writing, with the exception of a limited number of studies in the Middle East that each examined one particular aspect of Arabs' writing processes, namely revision (Alam 1993) and the use of Arabic when writing in English (Al-Semari 1993).

\section{Literature Review}

\subsection{Writing as a Process}

Perl (1980) stated that, 'For over one hundred years American colleges have offered courses in written composition, but only in the past ten years have researchers begun to study how people 
write' (p. 13). Only when Braddock, Lloyd-Jones, and Schoer (1963) asked, 'What is involved in the act of writing?' (p. 53) did some researchers and composition instructors start to challenge the product-oriented composition pedagogy.

Emig (1971) pointed out that 'of the 504 studies written before 1963 that are quoted in the bibliography of Research in Written Composition, only two indirectly address the process of writing among adolescents' (p. 19). One is 'The Sound of Writing' by Anthony Tovatt and Ebert L. Miller; the other is 'Pre-writing: the Construction and Application of Models for Concept Formation in Writing' by D. Gordon Rohman and Albert O. Wieck (Emig 1971, 20). Therefore, the landmark research of Emig (1971) truly responded to the shift from product to process (Krapels 1990). Emig pioneered a case-study approach implementing the method of verbal reporting, observation, and post-event interviewing techniques, representing a breakthrough for writing research by introducing a more scientific way to study the writing process and to illuminate what writers were actually doing when they were writing.

Emig met four times with her subjects, eight L1 English school seniors who were selected by their teachers as being good writers. She observed the students speaking aloud to express themselves while they wrote, took notes, and recorded this writing-aloud process. Moreover, she interviewed the subjects and collected their preliminary notes, outlines, and final written products. The most important contribution from Emig was the revelation of the complex, non-linear nature of the writing process among her subjects; she called attention to the importance of pre-planning and editing as ongoing strategies. In other words, the writing process was recursive rather than linear; this is one of the hypotheses in our study. The study by Emig, therefore, provided not only new insights but also a research design for the investigation of writing processes; it presented a breakthrough for writing research by legitimising the case-study approach, the think-aloud methodology, and the study of pauses, as well as revealing the role of re-reading in revision and the amount and type of revision among writers (Faigley 1986).

The main drawback of Emig's study is that it used eight students to participate in the study, who were selected according to their rating from their teacher; Emig did not investigate their writing proficiency herself. Therefore, in the present study, we measured the writing proficiency of as many subjects as possible.

Further, researchers such as Perl (1979) and Pianko (1979) looked at the composition processes of basic writers to investigate the problems faced by those writers during the writing process. For example, Perl (1979), using the case-study method, audiotaped five L1 college students categorised as 'unskilled' writers. Data were collected from the subjects' written products, audiotapes of their think-aloud composition process, and interviews. The perceptions and memories of writing reported by the subjects were analysed. Perl created a composition style sheet from the data and used it to summarise writing patterns and strategies. According to Perl $(1978,1980)$, writing is a recursive process through which the writer juggles various elements of text already written to produce more text. Using the think-aloud technique, Perl observed that the occurrence of recursive portions, which are not always easy to identify, differ among writers and topics. 
In her study of the writing process of five native English-speaking unskilled college writers, Perl (1978) devised a coding system, which she used in her study after students had finished writing, to describe the writing process by focusing on students' written products and the audiotaped thinking-aloud portions of the sessions. She added that her methods were devised 'to assist in answering the question "How do writers compose?"' These are process measures, or ways of depicting what writers do as they write, moment by moment. As such, it is a descriptive method for portraying composition strategies as they emerge in sequence (p. 3). Further, Perl described the coding system as a scheme that 'allows us to observe the composition process as it unfolds. It allows us to record exactly what is going on while it is occurring and then to return to the data for analysis. It provides writers who think they 'don't know how to write' with an opportunity to see that they do have a process all their own. It offers writers who think they know a lot about their own process an opportunity to check their perceptions about themselves. Often the results are surprising' (p. 4).

Perl claimed that this coding scheme 'can be replicated and applied to data from a range of different cases' (p. 1). She concluded that the scheme may be modified and new categories may need to be added.

As a consequence, writing researchers and teachers shifted their concern from the written text that students produced to helping students to write better by aiding them in the actual process of writing, finding the sources of their problems in creating well-written texts, and helping them to overcome those problems. Such ideas also dovetailed well with ideas expressed in the late 1970s and early 1980s in numerous articles such as those by Murray (1980), whose ideas emphasised the importance of a series of drafts in the writing process as writers gradually discover through writing what they want to say.

Therefore, a process approach was born, which made it clear that the teaching of writing should focus on the writing process rather than on the final product. Nevertheless, this was a teaching approach, not a teaching method; pedagogical methods and means were not laid down or even clearly implied by most of those who conducted empirical research into the writing process.

\subsection{Planning Strategies}

In research on writing, planning has been viewed as one of several processes involved in the production of written text (Ellis and Yuan 2004). Its role, therefore, should be considered in relation to other composition processes. This has been addressed through models of the complete writing process. Graves and Murray (1980) admitted that planning includes such diverse prewriting or rehearsal activities as drawing and making notes about the topic when ideas are being incubated, in addition to setting goals and generating and organising content. Hayes and Gradwohl (1996) considered planning to be a type of reflection, to be examined along with other reflective processes. They argued that planning can be distinguished from other types of reflection because it occurs in an environment different from that of the task itself. They argue that there are two types of planning: process planning and text planning. Process planning is focused on the writer and how the task is to be performed, whereas text planning is focused on the content and form of what is to be written. This can entail abstract text planning that leads to 
the production of ideas, notes, and outlines involving content and rhetorical organisation, language planning, or both.

Whalen and Menard (1995) discussed planning in terms of the discourse levels involved. Pragmatic planning involves defining pragmatic objectives (i.e. identifying the audience and a personal or professional reason to write and detailing the content of the topic). Textual planning entails determining an appropriate text typology and how to achieve coherence between sequences of ideas. Finally, linguistics planning occurs when the writer attempts to solve a linguistic problem to formulate an idea. Hayes and Gradwohl (1996) reviewed a number of studies investigating the effect of planning and concluded that 'the effect of planning on text quality is almost entirely attributable to time on task' and that 'planning is neither more nor less valuable than other writing activities' (p. 53). In other words, planning leads to better-quality texts and greater fluency in writing simply because it affords learners more time overall to be spent on writing.

\section{Methods}

\subsection{Participants}

The subjects of the study were 197 Saudi third-year undergraduate students studying at the Department of English at the University of Ha'il, Saudi Arabia, in the academic year 2009 to 2010.

\subsection{Instruments of the Study}

\subsubsection{Assessment of Writing Proficiency}

As a means of assessing writing proficiency, the students were asked to participate in the proficiency measure of writing. They were told that their participation was voluntary.

\subsubsection{Choice of Topics}

The argumentative essay type was chosen because the aim of this assessment was to distinguish between good and poor writers. Previous research indicates a much wider range of differences in the quality of argumentative writing compared with other writing types and higher cognitive capacity engagement in this mode of discourse (Freedman and Pringle 1984, Andrews 1995). Argumentative-type writing is considered by most teachers to be academically rigorous, challenging, and probably more difficult than the narrative style; therefore, this style best reflects students’ writing ability.

The students were not given a list of topics from which to choose because allowing a choice of topics would introduce too much uncontrolled variance into the study (i.e. differences in scores that cannot be interpreted as occurring due to writing proficiency differences but to different topics). Jacobs et al (1981) indicated that 'there is no completely reliable basis for comparison of scores on a test unless all the students have performed the same writing task(s)' (p. 16). Hence, the topic was carefully selected to reflect students' cultural background. The researcher wanted to control the amount of background knowledge the students had of the topic so he chose a topic for which all students had a lot of knowledge but on which they had not previously written, as 
verified by the students' teachers. Hence, students would be able to fully retrieve topic-related information from their own experience and knowledge. The topic assigned for the proficiency measure in writing was 'Success in education is influenced more by students' home life and training as a child than by the quality and effectiveness of the educational program. Do you agree or disagree?'

\subsubsection{Procedure}

The students who volunteered for the study were asked to handwrite an argumentative essay in English. The writing sample was collected under carefully controlled conditions. The students were neither allowed to talk to their peers nor to ask the questions about the topic. Additionally, dictionaries were not allowed because the researcher wanted to put his subjects in an examination-like situation. The purpose of this writing task was to group students according to their writing proficiency, which is a key variable in our study.

\subsubsection{Scoring}

The essays were rated on content, organisation, vocabulary, language use (i.e. grammar), and mechanics, according to a criterion-referenced rating instrument from the English as a Second Language (ESL) Composition Profile developed by Jacobs et al (1981). This instrument was chosen for its reliability and endorsement by other researchers. According to Haswell (2005), it was called 'ESL Composition Profile' because since this scoring guide was published in 1981, it has proved very popular. Its reliability derives from the fact that it is broken down into evaluative ratings of separate aspects of writing rather than yielding one single overall rating. The more one breaks the scoring into additional parts, the more reliable is the profile. The main features of the ESL Composition Profile (Haswell 2005, 107) are as follows:

- It has a limited number of basic criteria or main traits (e.g. content, organisation, vocabulary, language use, grammar, and mechanics).

- Each trait fits into a proficiency scale, the levels of which are also small in number and usually homologous or corresponding (e.g. 1, 2, 3, or 4 for each trait).

- Each trait is broken down into subtraits, which are also small in number and homologous or corresponding. For instance, there are four subtraits, each with corresponding levels of the main trait content in Jacobs et al (1981): knowledge of the topic, substance, development of the topic, and relevance. It should be noted that the homology does not allow for writers who have 'a limited knowledge' of the topic but applies what little they know in a manner that is relevant to the topic.

Haswell reported that the ESL Composition Profile encourages an evaluation of student proficiency. which is complex, It is probably able to record high achievement in content yet low achievement in mechanics, a complexity that suits writers who often show rough writing skill in a second language. Thus, this profile differs with holistic scoring methods, which remove the possible roughness in writing achievements by reporting a single score. However, the kind of rating that underlies the ESL Composition Profile is the same as the holistic rating in that it merely asks the rater to carry out the holistic rating process five times. Further, the limited 
number of traits allows comparison of group rating behaviour, probably contrasting the way native and non-native English-speaking faculty evaluate ESL and EFL essays. In addition, the scaling of traits and subtraits allows study of rater reliability along with the development of training methods that produce high inter-rater reliability coefficients needed to defend the results of commercial testing or research studies. Finally, the decrease of rough and otherwise complex writing proficiency to units, as well as the internal ordering of traits or subtraits as homologous and mutually exclusive, allow the generation of empirical outcomes useful in research, placement, and program validation (Haswell 2005; 107, 110).

Secondly, the researcher decided to use this instrument in this study because it has been used by other researchers (e.g. Chaudron 1984, Hvitefldt 1986, Al-Hazmi 1998, and El Mortaji 2002). It was described as 'the best-known scoring procedure for ESL writing at the present time' (Hamp-Lyons 1990, 87). Further, it is not very different from the methods with which the teachers in SA are already familiar.

According to this profile, readers make five holistic evaluations of the same composition, each from a different perspective: content (30 points), organisation (20 points), vocabulary (20 points), language use (25 points), and mechanics (5 points). The total score can range from 100 (maximum) to 34 (minimum). The individual scales and the overall summed scale are further broken down by Jacobs into numerical ranges that correspond to four mastery levels: excellent to very good (83-100 points), good to average (63-82 points), fair to poor (52-63 points), and very poor (34-52 points). As Jacobs states, 'These levels are characterised and differentiated by key words or "rubrics” representing specific criteria for excellence in composition'. To divide our students into groups to select them for interviewing, as well as to use their data for the main analysis, the researcher decided to designate those who scored between 34 and 62 as poor writers and designate those whose scored between 63 and 100 as good writers. In fact, the cut off score of 63 given by Jacobs et al (1981) is said by those authors to serve as a broad dividing line between the fair and good writing levels: any score of 63 of higher is considered to be good to excellent and any score below 63 is considered fair to poor. The results showed that 91 students were rated as good writers and 103 as poor writers.

\subsubsection{Classification of Good and Poor Writers}

The researcher contacted some of the university lecturers who teach the students in our cohort to rate the students' argumentative essays. The essays were evaluated by two different raters. The researcher provided the lecturers with a complete set of essays, correction criteria, and a letter of request. Moreover, the researcher held two sessions with each rater during which he trained them separately and discussed any point that the raters might raise before they assessed the writing samples. The researcher substituted code numbers for the students' names to preserve the anonymity of those students. By following the procedure stated by Jacobs et al (1981), each essay was read by at least two raters; if there was more than a 10-point variation in the total scores of the two raters, the essays were to be judged by a third rater, and the final score of the essay was to be based on the average of the two closest scores. In this study, we did not need a third rater because the scores of the two raters were highly similar, with approximately a three-point maximum variation. 


\subsubsection{Questionnaire}

The questionnaire in our study was developed based on a careful examination of the questionnaires and think-aloud studies used by El Mortaji (2001), Sang-Hee (2002), Alnofl (2003), and El-Aswad (2003). Further, the researcher designed many of questions, all of which were reviewed by two professors of applied linguistics as a form of content validation. Considerable attempts were made to ensure the content validity of this instrument by reference to items in the previous studies referred herein. The Arabic version of the questionnaire was discussed and checked by professional Arabic-language teachers to ensure content validity and to avoid any ambiguity in the wording of the questionnaire that could lead to problems of interpretation on the part of the respondents. Moreover, we checked that the terminologies used would definitely be known and understood by the participants.

A total of sixteen statements are included in the questionnaire. The students were asked to rate the statements using one of the following responses: (1) never, (2) seldom, (3) sometimes, (4) often, or (5) always.

\subsubsection{Interview}

The semi-structured interview used a schedule of questions that strongly resembled those in a questionnaire. The questions were open and the responses were taped for later transcription.

\subsection{Data Collection and Analysis}

The questionnaire was administered to the students by the classroom teacher during a regular class period (spring 2009-2010). The full descriptive instructions regarding the procedures of administration were provided to, and discussed with class instructors before the administration. The students were told that there were no right or wrong answers to any question, and that their confidentiality was secured and their responses would be used for research purposes only. They were also informed that while their participation would not affect their grades, they still had the option not to participate.

Data was analysed using SPSS. The data was analysed using frequency, means, and standard deviation to identify the strategies used. A two-way repeated measure ANOVA was used with a post hoc comparison test to investigate the variation in strategies used by the participants.

\section{Results}

In this section, the researcher explores differences in the frequency of use of WPSs by Saudi male students. The mean frequency ratings of the statements in table 1, range from 2.65 (1.32) through 4.28 (1.04). Of note, most of these planning strategies yielded a mean rating between 3.00 and 4.00 . 
Table 1. Mean frequency of use of English PLs used by all subjects

\begin{tabular}{|c|c|c|}
\hline English Planning Strategies & Mean & SD \\
\hline 1.I discuss the topic with others & 3.30 & 1.35 \\
\hline $\begin{array}{l}\text { 2. If the topic is not known to me, I decide to write about ideas that are } \\
\text { closely, although not strictly relevant. }\end{array}$ & 3.39 & 1.24 \\
\hline 3. I create a mental plan for the ideas in Arabic. & 3.77 & 1.25 \\
\hline 4. I create a mental plan for the ideas in English. & 3.22 & 1.25 \\
\hline 5. I create a written plan for the ideas in Arabic. & 3.12 & 1.46 \\
\hline 6. I create a written plan for the ideas in English. & 3.08 & 1.23 \\
\hline $\begin{array}{l}\text { 7. Before I start writing, I create a mental plan for the entire content and } \\
\text { organisation in Arabic. }\end{array}$ & 2.69 & 1.29 \\
\hline $\begin{array}{l}\text { 8. Before I start writing, I create a mental plan for the entire content and } \\
\text { organisation in English. }\end{array}$ & 2.71 & 1.25 \\
\hline $\begin{array}{l}\text { 9. Before I start writing, I create a written plan for the entire content and } \\
\text { organisation in Arabic. }\end{array}$ & 2.65 & 1.32 \\
\hline $\begin{array}{l}\text { 10. Before I start writing, I create a written plan for the entire content and } \\
\text { organisation in English. }\end{array}$ & 3.02 & 1.28 \\
\hline 11. When I write, I think about the purpose of my writing. & 3.84 & 1.16 \\
\hline 12. When writing, I think about the reader of my writing. & 4.28 & 1.04 \\
\hline $\begin{array}{l}\text { 13. When I am planning, I rehearse for the actual words and phrases that I } \\
\text { might use. }\end{array}$ & 4.05 & .934 \\
\hline 14.I switch from L2 to L1 in order to plan & 2.97 & 1.27 \\
\hline 15.I switch from L1 to L2 in order to plan & 3.11 & 1.28 \\
\hline 16. I plan the wording of each specific part of the text just before I write it & 3.77 & 1.06 \\
\hline
\end{tabular}


Thinking about the reader of one's writing is reported as the planning strategy most frequently used by Saudi male students, with a frequency rating of 4.28 and SD (1.04). In studies involving L2 writers, including this study, the notion of audience is recognised to be fundamental to writing in the English language. The students' responses during their interviews showed their awareness of an audience; they demonstrated that when they write, they bear in mind the reader of their writing, usually their teacher. Thus, they focus on the aspects with which the reader is concerned, such as correctness of language. Also, the students in our study demonstrated that they would write differently for a different reader, as illustrated in the transcript of the interview with subject 16 , who said, 'When writing, I keep in my mind the reader of my essay, who would usually be my teacher. But if I write to another reader, I would write differently, I mean I will see what the new reader focuses on and do it.' This parallels the findings of other studies, such those by as Brooks (1985), Al-Semari (1993), and Li (1999).

Comparing all sixteen WPSs, our results are significant according to one-way repeated measures ANOVA ( $F=35.202, P=.001)$. Multiple comparisons with Bonferroni adjustment showed that, as stated by subject 13 , 'thinking about the reader of [my] writing is significantly different from all the strategies except...when I am planning, I rehearse the actual words and phrases that I might use'.

Rehearsing the actual words and phrases that might be used is reported to be the second most popular planning strategy. This finding agrees with those of Alnofal (2003) and El-Aswad (2002), most of whose subjects asserted that they always planned carefully and looked for words and phrases they wanted to use. Generally, during the brainstorming phase, thinking of words and even writing related words, phrases, and sentences that articulate ideas pertaining to a specific topic help learners to activate this kind of linguistic knowledge and rhetoric. Hence, these techniques are not only effective for carrying out the writing task but also serve as a form of practice and rehearsal for further mastery, consequently enhancing the process of language acquisition. In response to the question about the characteristics of a good English-language essay, our subjects demonstrated that one of the major characteristics is to avoid repetition and to use a wide variety of vocabulary.

Thinking about the purpose of writing was ranked the third most important planning strategy used by Saudi male EFL students. The students reported in their interviews that they usually keep the purpose of writing in mind as they try to present ideas, to convey their message, and to achieve the purpose of the essay. For example, for a descriptive essay, they try to describe details; for an argumentative essay, they attempt to argue and to show their opinions. For example, subject 2 said, 'Keeping the purpose of writing in your mind is very important, as it helps you to focus on the type of essay and try to cover it and present ideas and convey the message.' Further, subject 6 said, 'I always [try] to keep the purpose of writing in my mind because if I am asked to write a descriptive essay, I try to describe everything, and if the essay I am writing is argumentative, I try to present my argument logically and show my opinion.' This parallels the findings of other studies, such as those by Al-Semari (1993). Nevertheless, our finding is inconsistent with that of Victori (1999), who found that none of her subjects overtly expressed, in the interview or the protocol, any concern for purpose. Thus, their state of mind on this point could be inferred only from what they had written. However, it could be argued that finding this 
might be attributed to her subjects, who had been classified as poor writers; immediately after stating their opinions, they were reported to have experienced great difficulties in generating more content. Hence, they seemed to be limited to presenting ideas and opinions without much argumentation to back them up. A drawback of that study is its small sample size, namely, four undergraduate university Spanish-language students.

Planning the wording of each specific part of the text just before writing it ranked fourth among the planning strategies used by Saudi male students, with a frequency rating of 3.77 and SD (1.06). This finding agrees with that of El-Aswad (2002), who found that most of his subjects adopted local planning of words with single sentences or with each paragraph separately. He argued that this type of planning guided the subjects' writing process and made them remember that they needed other paragraphs to support the first. This finding is in line with the subjects' responses in the interview: they reported that they prefer to plan the wording of each specific part of the essay to be sure that they use suitable and appropriate words, cover all ideas, ensure that all the paragraphs develop well, and ensure that each idea in a paragraph supports the ideas that follow it. For example, subject 11 said, 'When I write an essay in English (L2), I prefer to plan the wording of each specific part separately in order not to use confusing words and not to miss any idea.'

Creating a mental plan for the ideas in Arabic was the fifth most popular among the planning strategies used by Saudi male EFL learners. This agrees with the findings of Uzawa and Cumming (1989), Pennington and So (1993), El-Aswad (2002), and Cohen and Brooks-Carson (2001), who found that their subjects thought and organised their ideas in their L1 and then translated ideas into the $\mathrm{L} 2$, rather than proceeding directly from the concepts to their L2 representation. The students' responses in their interviews indicated that they use their L1 (i.e. Arabic) and create mental plans for ideas in their L1 to aid their writing in their L2.

Deciding to write about ideas that are close to the topic, although not strictly relevant if the topic is unknown, ranked sixth among PLs and is reported generally at higher than 3 on our scale (i.e. 'sometimes'). In other words, our subjects do not rely heavily on this strategy; this agrees with the findings of Junju (2004). In the present study, the students' responses in the interview support this finding. The students demonstrated that sometimes they had encountered great difficulties in their writing processes regarding the generation of ideas about the topic; therefore, they tended to write about ideas even if they are not relevant to the topic. For instance, subject 19 said, 'Sometimes when I write about a certain topic, I face the problem of generating relevant ideas and in this case, I tended to write about close ideas, although [they were] not so relevant.'

Discussing the topic with others (e.g. the teacher) was reported to be the seventh most commonly used planning strategy. To the best of the researcher's knowledge, in English-language writing courses, teachers lead an open discussion with the students in English before they start writing on the topic. The students reported that they sometimes discuss the topic with others to obtain clear knowledge about it and to see different opinions and ideas, which would help them to create their own topic. This agrees with the findings of Zamel (1982). 
Creating a mental plan for ideas in English was reported to be the ninth most common planning strategy used by our subjects. This is consistent with the findings of Rashid (1996) and El-Aswad (2002), who found that their subjects took time to plan locally in their minds for ideas in English. In other words, they thought of ideas in English, clearly before actual writing took place, and while writing, they would explore, elaborate, and develop their ideas fully.

Creating a written plan for ideas in Arabic appears to be a less popular strategy because it ranked tenth among the planning strategies used by Saudi male EFL learners. Further, it was among the seven least-used WPSs. The students admitted that sometimes the topic is too long and requires a lot of information so they tend to write some ideas in Arabic to help them avoid forgetting any ideas. This parallels the findings of other research such as Uzawa and Cumming (1989), Khaldiah (200_), and Woodall (2002), who found that some of their subjects wrote out notes in their L1.

As expected by the researcher, subjects would switch back and forth from one language to another, particularly from their L1 to their L2; more surprisingly, switching from L1 to L2 in order to plan was the eleventh most common PLS used by Saudi male EFL students. That strategy is used more often than switching from L2 to L1 for planning; however, results of the Wilcoxon test show no significant difference $(z=-1.353 ; P=.176)$. In any case, this type of strategy is not very popular among our subjects. The interview answers support this finding: our students start to plan in one language and change during the last part of the planning process to the other language, as the students illustrated in the interview. For example, subject 6 said, 'Actually, when I write in [my] L2, I sometimes switch from one language to the other; what I mean is that when I start planning, I switch from [my] L2 to [my] L1 or from [my] L1 to [my] L2.' Further, subject 20 said, 'When planning my essay, I start in one language and then change to the other language for the last part.' This finding agrees with that of El Mortaji (2001), who called this type of switching intentional language switch.

Creating a written plan for ideas in English was reported to be the twelfth most popular WPS used by our subjects; in other words, it is not popular among Saudi male students. This could be because they prefer to write their plans in Arabic rather than in English, and writing a plan requires more effort than forming it mentally. This theory agrees with the finding of Junju (2004), who found that her subjects, whom she commented had poor command of English (their L2), rarely create written plans in English.

Creating a written plan for the entire content and organisation of one's writing in English before starting to write ranked as the thirteenth most popular PLS used by our subjects, with a mean (SD) frequency rating of 3.02 (1.28). To explain this finding, it could be argued that the lack of L2 proficiency among the cohort caused it to be used less often. The interviewees' responses support this finding: the interviewees admitted to sketching a rough outline for the entire content in English to prepare themselves before they began to write the composition; however, this happened only occasionally if the topic was easy and they knew enough words and expressions to write on the topic in English. Switching from one's L2 to one's L1 to plan was the fourteenth most popular WPS used by Saudi male EFL learners. Therefore, the subjects reported that they switch from their L2 to their L1 to plan their essays and that this facilitated the act of writing for 


\section{Macrothink}

International Journal of Linguistics

ISSN 1948-5425

2012, Vol. 4, No. 3

them. For example, subject 18 said, 'When I write in English ([my] L2), I switch from [my] L2 to [my] L1, which could help me in planning and facilitate my writing.' The subjects reported switching to their L1 if they failed to generate ideas in English, believing that it would be easier to think in Arabic when writing in English because of their habit of thinking in Arabic in their everyday life. The students interviewed gave reasons for their switching from their L2 to their L1; for instance, subject 15 said, 'In fact, when I failed to generate my ideas in English, I switch to Arabic.' Another interviewee, subject 8, said, 'I switch from [my] L2 to [my] L1 when planning because I believed that thinking in Arabic is easier than in [my] L2, as I use my L1 everywhere.' This parallels the findings of other researchers, such as Raimes (1987), Rashid (1996), El-Aswad (2002), Wang (2003), and Junju (2004). These authors claimed that switches to their L1 during writing in their L2 occurred when the students were planning what to include and write.

Creating a mental plan for the entire content and organisation of one's writing in Arabic, doing the same in English, and creating a written plan in Arabic before starting to write in English ranked the fifteenth, sixteenth, and seventeenth most commonly used WPSs; in other words, these strategies were not popular among our subjects. Generally speaking, Saudi male students prefer to create local plans rather than global ones; this finding agrees with those of Rashid (1996) and El-Aswad (2002).

\subsection{English-language Writing Proficiency in Relation to Planning Strategies}

In this section, we examine the differences in the use of WPSs between good and poor writers. Thus, WPSs were divided into two groups, the first being planned content and 'when' strategies, the second being other Pls.

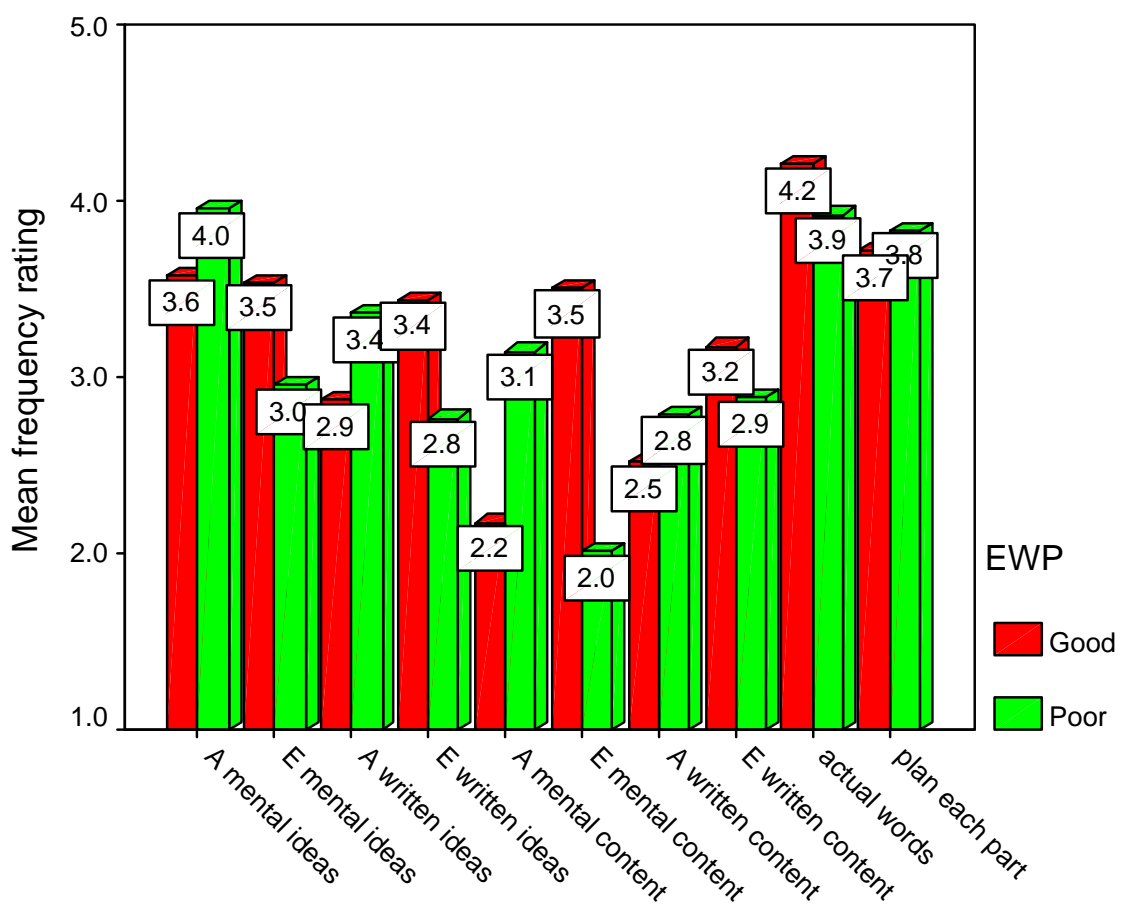

Figure 1 . The frequency rating with which good and poor writers use what is planned and when strategies in English 


\section{Macrothink}

International Journal of Linguistics

ISSN 1948-5425

2012, Vol. 4, No. 3

As seen in figure 1, good writers use five of the WPSs more frequently than do poor writers; the other five WPSs are reported to be used more frequently by poor writers than good writers. This finding could be related to the fact that all five of the other strategies require higher L2 proficiency; therefore, one might expect those strategies to be used with more success by better writers. In fact, the five strategies reported to be used more frequently by poor writers were L1 use-related strategies; in other words, the lower the writing proficiency, the higher is the use of the L1. Significant differences were found in the use of six WPSs, as illustrated in table 2. These significant differences can be sorted into strategies used more often by good writers than poor writers and strategies used more often by poor writers than good writers.

Table 2. Summary of the significant differences between good and poor writers in the use of English-language writing planning strategies

\begin{tabular}{|l|l|l|l|l|l|l|}
\hline \multirow{2}{*}{$\begin{array}{l}\text { English-language writing planning } \\
\text { strategies }\end{array}$} & \multicolumn{3}{|l|}{ Proficiency level of writers } & \multicolumn{2}{l}{ Inferential statisticsa } \\
\cline { 2 - 7 } & Good & SD & Mean & SD & z Value & P Value \\
\cline { 2 - 7 } & 3.54 & 1.14 & 2.95 & 1.29 & -3.25 & .001 \\
\hline $\begin{array}{l}\text { I create a mental plan for ideas in } \\
\text { English. }\end{array}$ & 3.44 & 1.22 & 2.77 & 1.16 & -3.95 & .001 \\
\hline $\begin{array}{l}\text { I create a written plan for ideas in } \\
\text { English. }\end{array}$ & 3.51 & .75 & 2.01 & 1.19 & -8.29 & .001 \\
\hline $\begin{array}{l}\text { Before I start writing, I create a mental } \\
\text { plan for the entire content and } \\
\text { organisation of my writing in English. }\end{array}$ & 4.21 & .86 & 3.92 & .98 & -2.16 & .031 \\
\hline $\begin{array}{l}\text { When I am planning, I rehearse the } \\
\text { actual words and phrases I might use. }\end{array}$ & 4.45 & .99 & 4.15 & 1.08 & -2.41 & .016 \\
\hline $\begin{array}{l}\text { When writing, I think about the reader } \\
\text { of my writing. }\end{array}$ & 2.87 & .1 .47 & 3.36 & 1.43 & -2.34 & .019 \\
\hline $\begin{array}{l}\text { I create a written plan for the ideas in } \\
\text { Arabic. }\end{array}$ & 2.18 & 1.31 & 3.15 & 1.11 & -5.75 & .001 \\
\hline $\begin{array}{l}\text { Before I start writing, I create a mental } \\
\text { plan for its entire content and } \\
\text { organisation in Arabic. }\end{array}$ & 2.79 & 1.30 & 3.15 & 1.23 & -2.02 & .043 \\
\hline $\begin{array}{l}\text { I switch from L2 to L1 to plan before } \\
\text { committing any ideas to paper. }\end{array}$ & & & & & & \\
\hline
\end{tabular}

Four strategies were found to be used more significantly by good writers than by poor writers. Table 2 and figure 1 show the significant relationship between WPSs and the use of creating a mental plan for ideas in English strategy $(z=-3.25, P=.001)$ : good writers use these strategies more often (mean 3.54 and SD [1.14]) than poor writers (mean 2.95 and SD [1.29]). This finding could be related to the fact that good writers are able to use the English language more extensively than poor writers.

Creating a written plan for ideas in English was also found to be used significantly more by good writers $(z=-3.95, P=.001)$. Further, a significant relationship was observed between EWP and 
the use of creating a mental plan for the entire content and organisation of one's writing in English $(z=-8.29, P=.001)$.

The results of Mann-Whitney testing show that EWP had a significant effect on the strategy of rehearsing the actual words and phrases that might be used $(z=-2.16, P=.031)$, indicating that the students with higher English writing proficiency were more likely to use this strategy. Moreover, good students presumably have a bigger vocabulary, making it more worthwhile for them to use the strategy. This finding is in line with that of Angelova (1999), who found that good writers more often tended to use that strategy.

Two strategies were found to be used more significantly by poor writers than good writers: creating a mental plan in Arabic for the entire content and organisation of one's writing $(z=-5.75$; $P=.001)$ and creating a written plan in Arabic for one's ideas, as can be seen clearly in table 4 and figure $4(z=-2.34 ; P=.019)$. This could occur because of lack of command of the English language among poor writers, consistent with the results reported by Rashid (1999).

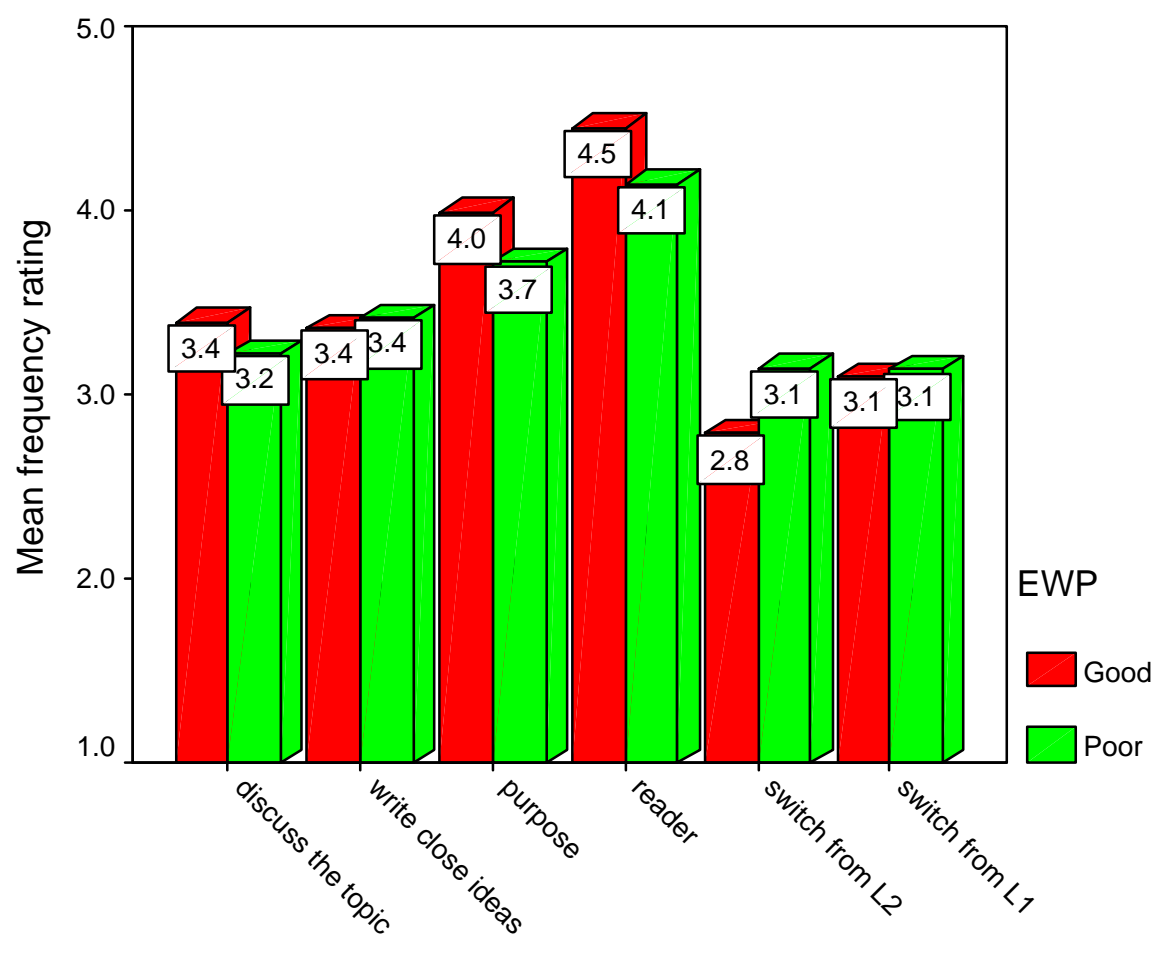

Figure 2. The frequency rating with which good and poor writers use other PLs in English

Figure 2 demonstrates that good writers use three WPSs more frequently than poor writers: thinking about the purpose of their writing, thinking about the reader of their writing, and discussing the topic with others (i.e. the teacher). This could occur because the first two strategies are more demanding and deeper than mere planning and because the third strategy requires higher L2 proficiency, given that the discussion should be in English. All three strategies, therefore, might be expected to be used by better writers. The only strategy found to be used more by poor writers than good ones was switching from one's L2 to one’s L1. Further, the final 
two strategies, writing about ideas close to the topic and switching from one's L1 to one's L2, are reported to be used almost equally by both groups.

A significant difference was found between good and poor writers in thinking about the reader ( $z$ $=-2.41 ; P=016$ ), as can be seen in table 4 and figure 4 , although both groups admitted their concern for the reader. This is consistent with the findings of Victori (1999); in their interviews, the two skilled writers, compared with the poor writers, made more reference to considering the targeted reader when writing. Nevertheless, some of the poor writers believed that when the text is addressed to the teacher, its content and, therefore, their opinion are not as important as linguistic accuracy. For instance, one student, a poor writer, answered an interview question by saying, 'I think [that] once my essay will be read by my teacher, linguistic accuracy is more important than the teacher's opinion.'). This finding agrees with that of Horwitz (1989).

A borderline difference was observed in the use of switching from one's L2 to one's L1 to plan ( $\mathrm{z}$ $=-2.02 ; P=.043$ ); poor writers rely more on switch to L1 than good writers. This finding is in line with those of Zamel (1982) and Rashid (1996). The use of one's native language in L2 writing could be necessary for students with limited English proficiency but may not be advisable for advanced ESL or EFL students. The major characteristic of the use of planning strategies is that for all PLs performed in one's L1, good writers used planning strategies less than poor writers, and on all PLs performed in L2, good writers used planning strategies more than poor writers. This finding agrees with those other researchers (such as Raimes [1985], Angelova [1999], and Junju [2004]), .showing that the use of planning strategies in L2 writing is differently dependent on EWP.

Some WPSs failed to yield a significant relationship with EWP; in other words, those who are good writers tend to plan more globally (mean [SD], 2.84 [.634]) than poor writers (mean [SD], 2.70 [.753]); however, no significant difference was shown $(z=-1.472, P=.141)$. The main reason we have suggested to explain the EWP differences is that the lower level of English-language proficiency among poor writers stops them using various L2 WPSs as often, which makes their writing poorer.

\section{Conclusion}

Much variation can be observed in the strategies the participants reported using when writing in their L2. In general, the participants reported applying most of the strategies in the questionnaire at levels higher than the midpoint of the scale. They reported applying only a few strategies at below level 3; however, all strategies were reported to have been used by at least one of the subjects. Concerning English writing proficiency and regarding the overall frequency of use of the WPSs detailed herein, a significant difference between good and poor writers was found in the frequency of the overall use of WPSs $(z=-2.527 ; P=.011)$. Looking at separate WPSs, it seems that good writers use most of the WPSs more frequently than poor writers. Nevertheless, some strategies were found to be used significantly more by poorer writers.

Regarding instruction in writing-strategy use, the results showed that most students are in need of training on how to write. This finding clearly indicates the inadequate amount of writing strategy 
instruction currently given to Saudi male EFL students. It is vital that this instruction gain formal recognition by being included in syllabi and curricula.

In conclusion, the present study explores WPSs in a new context (i.e. Saudi male EFL students), contributes to the field of L2 writing, and adds to the literature by giving new information about the use of writing strategies. We hope that this study offers helpful findings for the building of a more complete theory of EFL and ESL composition. We also hope that the current study will help curriculum designers and textbook writers produce books and teaching aids in ways that suit the learning behaviours of students and improve their achievement in their L1 and L2.

\subsection{Limitations of the Study}

Although this study was limited in some ways, none of those ways threatens the validity of the research. For instance, participants in this study were limited to undergraduate third-year Saudi male EFL students, which excludes undergraduate students at different years, graduate students, and female students. Further, students' participation in our study was voluntary (only 15 students declined to take part); therefore, the findings may be affected by motivation bias.

The study set out to investigate Saudi male EFL students' use of WPSs across different levels of writing proficiency. This does not deny that factors other than writing proficiency may also be relevant and may affect the use of WPSs. Hence, the present study does not take into account all possible factors. Further, it could not examine changes in the writing process over time or the adoption of WPSs as a result of writing instruction.

In addition, only the frequency of use was measured; no attempt was made to measure the effectiveness or successfulness of strategy use. We cannot tell, for example, if students with high and low proficiency who use the same strategy use it with equal effectiveness. Finally, as with all studies using questionnaires, and interviews, our study cannot illuminate the (presumably large) part of the writing process that is automatic and performed below the level of conscious awareness.

\subsection{Suggestions for Further Research}

The literature review presented in this study has revealed that Arab EFL writing processes and strategies, particularly those of Saudi male EFL students, have not been sufficiently investigated. Therefore, we highly recommend further research to conduct descriptive, experimental, and cross-sectional studies on Arab EFL learners, in general, and Saudi EFL students, in particular. These types of studies can give a more proper understanding of Arab and Saudi EFL writing processes.

Other studies should investigate the other English-language writing strategies, such as revision, formulating, and monitoring, used by Saudi students. Moreover, other studies should investigate the English-language writing strategies of Saudi students of both genders and of different ages and educational levels (i.e. intermediate, high school, and university).

Further research should examine English-language writing strategies of Saudi students at different levels of proficiency in English (i.e. beginning, intermediate, and advanced) to determine to what extent their proficiency level affects their writing strategies. Longitudinal 
studies would be valuable to examine changes in students' writing processes and strategies over time. Factors such as development of linguistic proficiency, information on the curriculum, and the influence of composition instruction on EFL students' writing processes could be investigated in broader scope.

In this study, the students were not given the topic in advance. Nevertheless, other researchers may want to give EFL writers the topics for writing tasks two or three days in advance of their participation to investigate the effect of this advanced notice on the quantity and quality of the writing strategies used by students. Moreover, further research should include topics chosen by the subjects themselves because doing so might involve other interesting cognitive processes not covered by this study.

Additional study is needed to determine the role of the L1 and how the L1 can be best used to facilitate writing. It is highly recommended that the role of contrastive rhetoric in the writing process be studied, to help EFL and ESL students prepare better for future academic settings. Additional research is needed to determine whether the use of translation is natural or necessary in the development of EFL writers.

Intervention studies should be conducted to seek to teach writing strategies and to measure their effects on writing performance. Either quasi-experimental or non-experimental studies could be performed in classroom settings in which teachers and researchers provide more or less explicit instruction to students regarding writing strategies and investigate students' written test scores, attitudes, and self-efficacy.

\section{References}

Abu-Shihab, I. (1986). The EFL composing process of the scientific second secondary students in Jordan. Unpublished MA thesis, Yarmouk University, Irbid, Jrdan.

Alam, M. M. (1993). The use of Arabic in the composing processes of Arab university students writing in English. Unpublished PhD thesis, Indiana University of Pennsylvania, Indiana, PA..

Aljamhoor, A. A. (1986). The English writing process of two Saudi graduate students before and after ESL instruction. Unpublished PhD thesis, Michigan State University, East Lansing, MI.

Alnofal, A. (2003). Arabic first language writing and English second language writing processes: a comparative study. Unpublished $\mathrm{PhD}$ thesis, the University of Kansas.

Al-Semari, O. (1993). Saudi students' revising strategies in Arabic and English essays. Unpublished $\mathrm{PhD}$ thesis, Michigan State University, East Lansing, MI.

Andrews, R. (1995). Teaching and learning argument. London: Cassel.

Angelova, M. (1999). An exploratory study of factors affecting the process and product of writing in English as a foreign language. Unpublished $\mathrm{PhD}$ thesis, State University of New York.

Braddock, R., Loyd-Jones, R., \& Schoer, L. (1963). Research in written composition. Champaign, IL. 
Brooks, A. (1996). An examination of native language processing in foreign language writing. Unpublished $\mathrm{PhD}$ thesis. Vanderbilt University, Nashville.

Brooks, E. (1985). Case studies of unskilled ESL college writers: a hypothesis about stages of development. ERIC Document 289-340.

Chaudron, C. (1984). The effects of feedback on students' composition revision. RELC Journal: A Journal of Language Teaching and Research in Southeast Asia, 15(2), 1-14.

Cohen, A., \& Brooks-Carson, A. (2001). Research on direct versus translated writing: students’ strategies and their results. The Modern Language Journal. 85, ii, 169-185. http://dx.doi.org/10.1111/0026-7902.00103

Cumming, A. (1987). Decision making and text representation in ESL writing performance. Paper presented at the The 21st Annual TESOL Convention, Miami.

Cumming, A. (1989). Writing expertise and second-language proficiency. Language Learning, 39, 81-141. http://dx.doi.org/10.1111/j.1467-1770.1989.tb00592.x

Cumming, A. (1990). Metalinguistic and ideational thinking in second language composing. Written Communication, 7, 482-511. http://dx.doi.org/10.1177/0741088390007004003

Cumming, A. (1995). Fostering writing expertise in ESL composition instruction: modelling and evaluation. In Belcher, D. and Brain, G. (eds.), Academic writing in a second language: Essays on research and pedagogy. pp. 375-391. Albex Publishing copporation, Norwood, NJ.

Cumming, A. (1998). Theoretical perspective on writing. Annual Review of Applied Linguistics, 18, 61-78. http://dx.doi.org/10.1017/S0267190500003482

Cumming, A. (2002). If I'd known twelve things. In Blanton, L., \& Kroll, B. (Eds.) ESL composition tales: reflections on teaching (pp. 123-134). Ann Arbor, MI: University of Michigan Press.

Cumming, A., \& Riazi, A. (2000). Building models of adult second-language writing instruction. Learning and Instruction, 10, 55-71. http://dx.doi.org/10.1016/S0959-4752(99)00018-3

Cummings, J. (1979). Cognitive/academic language proficiency, linguistics interdependence, the optimum age question and some other matters. Working paper in bilingualism. 19:197-205.

Cummings, J. (1980). The cross-lingual dimensions of language proficiency: implications for bilingual education and the optimal age issue. TESOL Quarterly, 14(2): 175-187. http://dx.doi.org/10.1016/S0959-4752(99)00018-3

El Mortaji. (2001). Writing ability and strategies in two discourse types: A cognitive study of multilingual Moroccan university students writing in Arabic (L1) and English (L3). Unpublished PhD thesis, University of Essex, UK.

El-Aswad, A. (2002). A study of the L1 and L2 writing processes and strategies of Arab learners with special refrences to third-year Libyan university students. Unpublished $\mathrm{PhD}$ thesis, University of Newcastle, Newcastle University library, UK 
Elkhatib, A. (1984). A classification of the lexical problems of ESL/EFL students. ERIC Doc. No. 246691.

Ellis, R. (1994). The Study of Second Language Acquisition. Oxford: Oxford University Press.

El-Sayed, A. (1992). Arabic rhetoric and its influence on the English writings of Arab university students. Indiana Journal of Applied Linguistics, 18(2), 43-65.

Emig, J. (1971). The composing processes of twelfth graders. Urbana, IL: National Council of Teachers of English.

Faigley, L., \& Witte, S. (1981). Analysing revision. College Composition and Communication, 32(4), 400-414. http://dx.doi.org/10.2307/356602

Faigley, L. (1986). 'Competing theories of process: A critique arid a proposal.” College English 41, 19-38.

Ferris, D. (1994). Rhetorical strategies in student persuasive writing: difference between native and non-native English speakers. Research in the Teaching of English, 28(1), 45-65.

Flower, L., \& Hayes, J. (1980a). Identifying the organization of writing processes. In Gregg, L. \& Steinberg, E. (EDs), Cognitive processes in writing, pp.3-30. Hillsadle, NJ: Lawrence Erlbaum Associates. http://dx.doi.org/10.2307/356600

Flower, L., \& Hayes, J. (1980b). The dynamic of composing: Making plans and juggling constraints. In Gregg, L. \& Steinberg, E. (EDs), Cognitive processes in writing, pp.31-50. Hillsadle, NJ: Lawrence Erlbaum Associates.

Flower, L., \& Hayes, J. (1981a). A cognitive process theory of writing. College Composition and Communication, 33, 365-387.

Flower, L., \& Hayes, J. (1981b). Plans that guide the composing process. In Frederiksen, C. and J. Dominic (eds.), Writing: The nature, development and teaching of written communication. Volum 2, 39-58. Hillsdale, NJ: Lawrence Erlbaum.

Flower, L., \& Hayes, J. (1984). Images, plans and prose: the re presentation of meaning in writing. Written Communication, 1, 120-160. http://dx.doi.org/10.1177/0741088384001001006

Flower, L. (1979). Writer-based prose: a cognitive basis for problems in writing. College English. 41(1), 19-37. http://dx.doi.org/10.2307/376357

Flower, L. (1984). Writer-based prose: a cognitive basis for problems in writing. In S. McKay (ed). Composing in a second language. 16-42. Rowley, MA: Newbury House Publishers, Inc.

Flower, L. (1989). Problem Solving Strategies for Writing ( $3^{\text {rd }}$ ed.), Harcourt Brace Jovanovich, Publishers, Orlando, Florida.

Flower, L. (1990). The role of task representation in reading-to-write. In Flower, L. Stein, V., Ackerman, J., Kantz, M., McCormic, K., and Peck.W, (eds.), Reading-To-Write: Exploring a Cognitive and Social Process. pp. 35-75. OUP, New York, Oxford. 
Flower, L. (1993). Survey research methods ( $2^{\text {nd }}$ ed.). New Burry Park, CA:Sage.

Flower, L. (1994). The constructions of negotiated meaning: a social cognitive theory of writing. Carbondale. IL: Southern Illinois Press.

Flower, L., \& Hayes, J. (1977). Problem-solving strategies and the writing process. College English, 39, 449-461. http://dx.doi.org/10.2307/375768

Flower, L., Hayes, J. Carey, L., Schriver,K., \& Stratman, J. (1986). Detection diagnosis, and the strategies of revision. College Composition and Communication, 37,1, 16-55. http://dx.doi.org/10.2307/357381

Freedman, A., \& I. Pringle, (1984). Why students cannot write arguments? English in education. 18 (2), 73-84. http://dx.doi.org/10.1111/j.1754-8845.1984.tb00668.x

Graves, D., \& Murray, D. (1980). Revision: in the writer's workshop and in the classroom. Journal of Education, 162 (2), 38-56.

Hamp-Lyons, L. (1990). Second language writing: assessment issues. In B. Kroll (ed). Second language writing. Cambridge: CUP.

Haswell, R. (2005). Researching teacher evaluation of second language writing via prototype theory. In Matsuda, P., and Silva, T. (eds). Second language writing research. 105-120. Lawrence Erlbaum Associates, London.

Jacobs, H., Steven, A., Deanne, R. Wormuth, V., Faye, H., \& Jane, B (1981). Testing ESL composition: a practical approach. Rowley, Massachusetts: Newbury house Publishers, Inc.

Jacobs, S. (1982), Composing and coherence: a process study. Paper presented at the $16^{\text {th }}$ annual TESOL convention, Honolulu.

Junju, W. (2004). An investigation of the writing processes of Chinese EFL learners: subprocesses, strategies and the role of the mother tongue. Ann Arbor: UMI.

Krapels, A. R. (1990). An overview of second language writing process research. In Kroll, B (Ed.), Second Language Writing: Research Insights for the Classroom. New York: Cambridge University Press.

Pennington, M. C. \& So, S. (1993). Comparing writing process and product across two languages: A study of 6 Singaporean university student writers. Journal of Second Language Writing, 2(1), 41-64. http://dx.doi.org/10.1016/1060-3743(93)90005-N

Pennington, M. C. (1993). Exploring the potential of word processing for non-native writers. Computers and the Humanities, 27(3), 149-163. http://dx.doi.org/10.1007/BF01830068

Perl, S. (1978). Five writers writing: case studies of the composing processes of unskilled college writers. Unpublished PhD, thesis. New York University.

Perl, S. (1979). The composing process of unskilled college writers. Research on the Teaching of English, 13(3), 17-336. 
Perl, S. (1980a). A look at basic writers in the process of composing. In Lawrence, N.an Daniel, R. (eds.), Basic Writing, pp, 13-32. Urbana, Illinois: National Council of Teachers of English.

Perl, S. (1980b). Understanding composing. College Composition and Communication, 31, 4, 363-369. http://dx.doi.org/10.2307/356586

Raimes, A. (1985). What unskilled ESL students do as they write: A classroom study of composing. TESOL Quarterly, 19(2), 229-258. http://dx.doi.org/10.2307/3586828

Raimes, A. (1987). Language proficiency, writing ability, and composition strategies: A study of ESL college student writers. Language Learning, 37, 439-468. http://dx.doi.org/10.1111/j.1467-1770.1987.tb00579.x

Raimes, A. (1991). Out of the woods: emerging traditions in the teaching of writing. TESOL Quarterly.25, 3, 407-429. http://dx.doi.org/10.2307/3586978

Rashid, R. (1996). The composing processes and strategies of four adult undergraduate level native Malay speakers of ESL/EFL: composition, English as a second language. Unpublished PhD thesis. Ohio State University.

Sang-Hee, Y. (2002). The writing strategies used by graduate students of English as a second language. Journal of the Applied Linguistics association of Korea, 18,2, 127-144.

Smith, F. (1989). Writing and The Writer. Heinman Educational Books.

Stein, V. (1990). Exploring the cognition of reading-to-write. In Flower, L. Stein, V., Ackerman, J., Kantz, M., McCormic, K., and Peck.W, (eds.), Reading-To-Write: Exploring a Cognitive and Social Process. pp. 119-143. OUP, New York, Oxford.

Stein, V. (1990). Using what you know. In Flower, L. Stein, V., Ackerman, J., Kantz, M., McCormic, K., and Peck.W, (eds.), Reading-To-Write: Exploring a Cognitive and Social Process. pp. 144-153. OUP, New York, Oxford.

Uzawa, K. (1996). Second language learners’ process of L1 writing, L2 writing, and translation from L1 into L2. Journal of Second Language Writing, 5(3), 271-294. http://dx.doi.org/10.1016/S1060-3743(96)90005-3

Uzawa, K., \& Cumming, A. (1989). Writing strategies in Japanese as foreign language: Lowering and keeping up the standards. The Canadian Modern Language Review, 46,1, 178-189.

Victori, M. (1999). An analysis of writing knowledge in EFL composing: a case study of two effective and two less effective writers. System, 27(4), 537-555. http://dx.doi.org/10.1016/S0346-251X(99)00049-4

Wang, L. (2003). Switching to first language among writers with differing second-language proficiency. Journal of Second Language Writing, 12, 347-375. http://dx.doi.org/10.1016/j.jslw.2003.08.003 


\section{Al Macrothink}

International Journal of Linguistics

ISSN 1948-5425

2012, Vol. 4, No. 3

Wang, W., \& Wen, Q. (2002). L1 use in the L2 composing process: an exploratory study of 16 Chinese EFL writers. Journal of Second Language Writing, 11, 225-246. http://dx.doi.org/10.1016/S1060-3743(02)00084-X

Whalen, K. (1988). Pilot study on the nature of difficulties in written expression in a second language: process and product? Bulletin of the CAAL, 10, 51-59.

Whalen, K., \& Menard, N. (1995). L1 and L2 writers' strategic and linguistic knowledge: a model of multiple-level discourse processing. Language Learning, 45, 381-418. http://dx.doi.org/10.1111/j.1467-1770.1995.tb00447.x

White, E. (1987). Writing Advance. Oxford. OUP.

Widdowson, H. (1983). Learning Purpose and Language Use. Oxford: OUP.

Widdowson, H. (1983). New starts and different Labs of failure. In Freedman, A., Pringle, I., and Yalden, J. (eds.), Learning To Write: First Language-Second Language. London: Longman.

Woodall, B. R. (2002). Language-switching: Using the First Language while writing in a Second Language. Journal of Second Language Writing, 11(1). http://dx.doi.org/10.1016/S1060-3743(01)00051-0

Zamel, V. (1976). Teaching composition in the ESL classroom: What we can learn form research in the teaching of English. TESOL Quarterly, 10(1), 67-76. http://dx.doi.org/10.2307/3585940

Zamel, V. (1982). Writing: The process of discovering meaning. TESOL Quarterly, 16(2), 195-209. http://dx.doi.org/10.2307/3586792

Zamel, V. (1983). The composing processes of advance ESL students: six case studies. TESOL Quarterly, 17(2), 165-187. http://dx.doi.org/10.2307/3586647 